\title{
EVALUASI KESESUAIAN PERAIRAN PANTAI TEUPIN LAYEU IBOIH SEBAGAI EKOWISATA BAHARI
}

\section{(SUITABILITY EVALUATION OF TEUPIN LAYEU IBOIH BEACH AS THE LOCATION OF MARINE ECOTOURISM)}

\author{
Dian Aswita ${ }^{1}$, M. Ali Sarong ${ }^{2}$, Sugianto ${ }^{3}$ \\ ${ }^{1}$ Fakultas Keguruan dan Ilmu Pendidikan Universitas Serambi Mekkah \\ ${ }^{2}$ Fakultas Keguruan dan Ilmu Pendidikan Universitas Syiah Kuala \\ ${ }^{3}$ Fakultas Pertanian Universitas Syiah Kuala \\ e-mail: aswita_dian@yahoo.com
}

\begin{abstract}
Abstrak
Pantai Teupin Layeu Iboih merupakan salah satu lokasi wisata yang berada di Kota Sabang dan merupakan salah satu lokasi wisata bahari yang mulai dikembangkan dari wisata massal menjadi ekowisata. Penelitian ini bertujuan untuk mengkaji kesesuaian Pantai Teupin Layeu Iboih sebagai lokasi ekowisata bahari, dilaksanakan pada bulan Maret sampai dengan Juni 2014. Pendekatan dan jenis penelitian bersifat deskriptif dengan menggunakan metode survai dan observasi lapangan. Parameter dalam penelitian ini adalah jenis terumbu karang, jenis ikan karang, kedalaman perairan, kecerahan perairan, tipe pantai, penutupan lahan pantai, material dasar perairan, dan jarak ketersediaan air tawar. Hasil penelitian yang diperoleh adalah Pantai Teupin Layeu Iboih memiliki kriteria sesuai sebagai kawasan ekowisata bahari untuk rekreasi pantai dengan nilai $73 \%$ dan sangat sesuai sebagai ekowisata bahari untuk diving dan snorkeling dengan nilai $86,7 \%$.
\end{abstract}

Kata kunci: ekowisata bahari, evaluasi, Iboih

\begin{abstract}
Teupin Layeu Iboih beach is one of the tourist locations in Sabang City and is one of the locations for marine tourism was developed from mass tourism to ecotourism. This research aimed to assess the suitability of Teupin Layeu Iboih beach as the location of marine ecotourism was carried out from March to June 2014. A descriptive approach was applied by using survey and field observations. The parameters collected are the type of coral reefs, the coral fish species, the water depth, the water transparency, the type of beach, the coastal land cover, the bottom material, and the distance of freshwater availability from the beach. Research showed that Teupin Layeu Iboih beach is suitable for marine ecotourism as a recreational area with a value of $73 \%$ and very suitable for diving and snorkeling with a value of $86.7 \%$.
\end{abstract}

Keywords: evaluation, Iboih, marine ecotourism

\section{PENDAHULUAN}

Ekowisata merupakan suatu kegiatan yang memanfaatkan sumber daya alam dalam bentuk wisata yang bertujuan untuk pendidikan, penelitian dan pelestarian lingkungan hidup serta bertujuan untuk meningkatkan ekonomi masyarakat dan negara. Ekowisata sebagai alat pembangunan 
yang berkelanjutan dan memberikan manfaat sosial, lingkungan serta ekonomi dalam jangka panjang dan menjadi prioritas yang tepat dalam pembangunan ekonomi negara (Barkauskiene and Vytautas, 2013). Ekowisata merupakan suatu upaya dalam mempromosikan perjalanan wisata yang bertanggung jawab dan memberikan kontribusi positif terhadap kelestarian lingkungan, sertauntuk meningkatkan kesejahteraan masyarakat lokal (Zambrano et al., 2010).

Pelaksanaan ekowisata didasari pada pemeliharaan keasliaan alam dan lingkungan, pemeliharaan keaslian adatistiadat masyarakat yang tinggal pada daerah setempat, serta menjaga kelestarian flora dan fauna yang terdapat pada wilayah tersebut. Stronza (2010) mengemukakan bahwa bagi masyarakat pedesaan dan masyarakat adat, ekowisata telah menjadi pintu bagi perekonomian global. Hal ini dikarenakan terjadinya peningkatan taraf hidup masyarakat setempat dengan mengembangkan penginapan, jalur hiking, restoran, penyedia perlengkapan wisata dan menjadi pemandu wisata bagi wisatawan.

Pelaksanaan ekowisata juga dilakukan pada wisata bahari. Ekowisata bahari adalah wisata yang berbasis pada sumber daya pesisir dan laut dengan menyertakan aspek pendidikan dan interpretasi terhadap lingkungan dan budaya masyarakat. Ekowisata bahari merupakan bentuk pengelolaan sumber daya pesisir dan laut yang dikembangkan dengan pendekatan konservasi (Ketjulan, 2011). Tuwo (2011), mengemukakan bahwa "Ekowisata bahari merupakan bentuk wisata yang dikelola dengan pendekatan berkelanjutan, dimana: (1) pengelolaan alam diarahkan pada kelestarian sumber daya pesisir dan laut, (2) pengelolaan budaya diarahkan pada kesejahteraan masyarakat pesisir, (3) kegiatan konservasi diarahkan untuk menjaga keberlangsungan pemanfaatan sumber daya yang dimiliki secara berkelanjutan". Penerapan ekowisata bahari pada kawasan pesisir merupakan suatu program pemanfaatan lingkungan dengan keuntungan ganda, yaitu mendapat keun-tungan di bidang ekonomi dan keuntungan terhadap berkelanjutannya ekosistem alam (Triyuniarthi, 2011). Aktivitas yang dilakukan pada ekowisata bahari berorientasi pada air, yaitu renang, berlayar dengan perahu, diving, snorkeling, memancing, dan wisata pantai.

Salah satu lokasi wisata yang ada di Pulau Sabang dan merupakan kawasan pengembangan pariwisata adalah Pantai Teupin Layeu Iboih. Kawasan ini merupakan salah satu objek wisata bahari yang paling banyak dikunjungi karena beragamnya aktivitas wisata yang disediakan. Hal ini sesuai dengan penelitian yang dilakukan oleh Ramadhani dan Asep (2010), yang menyatakan bahwa lokasi yang paling diminati di Kota Sabang adalah Pantai Gapang, Tugu KM 0, dan Pantai Iboih, sedangkan kegiatan utama wisatawan berturut-turut adalah mengunjungi pantai, 
menyelam dan renang, mengunjungi tempat sejarah, memancing dan belanja.

Tingginya aktivitas kunjungan wisata di Pantai Teupin Layeu Iboih tentu dapat memberikan dampak negatif bagi lingkungan, oleh sebab itu, Pantai Teupin Layeu Iboih merupakan salah satu lokasi wisata bahari yang mulai dikembangkan dari wisata massal menjadi ekowisata. Namun demikian, data yang menyajikan tentang evaluasi kesesuaian Pantai Teupin Layeu Iboih sebagai kawasan ekowisata bahari berdasarkan keragaman sumber daya yang dimiliki dan karakteristik pantainya belum ditemukan, oleh karena itu penelitian ini bertujuan untuk mengkaji kesesuaian Pantai Teupin Layeu Iboih sebagai lokasi ekowisata bahari.

\section{METODE PENELITIAN}

Penelitian ini dilaksanakan di Pantai Teupin Layeu Iboih Kecamatan Sukakarya Kota Sabang, secara geografis berada antara 05'52'20'-05'52'34" LU dan 95'15'21'$95^{\circ} 15^{\prime} 32^{\prime \prime}$ BT dengan luas wilayah 6,42 Ha. Penelitian lapangan dilaksanakan pada bulan Maret 2014 sampai dengan bulan Juni 2014.

Instrumen penelitian yang digunakan dalam penelitian ini adalah secchi disk, alat tulis, batu duga, kamera digital, kamera air, scuba diving equipment, peralatan snorkeling, meteran, peta administrasi Iboih dan lembar observasi.

Penelitian dibedakan menjadi dua tahap, yaitu pengumpulan data keragaman sumber daya alam dan kondisi fisik lokasi penelitian. Pengumpulan data dilakukan dengan metode survai dan observasi lapangan. Evaluasi kesesuaian ekowisata bahari dibedakan menjadi dua, yaitu kesesuaian Pantai Teupin Layeu Iboih untuk rekreasi dan kesesuaian Pantai Teupin Layeu Iboih untuk kegiatan diving dan snorkeling. Evaluasi ini dilakukan dengan menganalisis semua parameter yang telah ditetapkan dan dilakukan pemberian skor, sehingga didapatkan nilai kesesuaian dari keseluruhan parameter.

Parameter dalam penelitian disajikan pada Tabel 1 dan Tabel 2. Tabel 1 dan Tabel 2 dijadikan acuan dalam evaluasi kesesuaian lahan, baik ekowisata bahari untuk rekreasi pantai maupun ekowisata bahari untuk aktivitas diving dan snorkeling.

Data yang telah dikumpulkan diolah secara deskriptif dengan menjelaskan karakteristik Pantai Teupin Layeu Iboih. Tingkat kesesuaian lokasi sebagai kawasan ekowisata bahari untuk rekreasi pantai dan aktivitas diving dan snorkeling dianalisis dengan menggunakan rumus Indeks Kesesuaian Wisata (Cahyadinata, 2009) sebagai berikut:

$$
\mathrm{IKW}=\sum(\mathrm{Ni} / \mathrm{Nmaks}) \times 100 \%
$$

Keterangan:

IKW = ndeks kesesuaian wisata

$\mathrm{INi}=$ Nilai parameter (Bobot $\mathrm{x}$ Skor)

Nmaks = Nilai maksimum dari kategori wisata bahari 
Jurnal Penelitian Saintek, Vol. 20, Nomor 1, April 2015

Tabel 1. Matriks Kesesuaian Lahan untuk Ekowisata Bahari (Rekreasi Pantai)

\begin{tabular}{|c|c|c|c|c|c|c|c|c|c|c|}
\hline \multirow{2}{*}{ No } & \multirow{2}{*}{ Parameter } & \multirow{2}{*}{ Bobot } & \multicolumn{8}{|c|}{ Kategori dan Skor } \\
\hline & & & Kategori & Skor & Kategori & Skor & Kategori & Skor & Kategori & Skor \\
\hline 1 & $\begin{array}{l}\text { Kedalaman } \\
\text { Perairan }(\mathrm{m})\end{array}$ & 4 & $0-5$ & 4 & $>5-10$ & 3 & $>10-15$ & 2 & $>15$ & 1 \\
\hline 2 & $\begin{array}{l}\text { Kecerahan } \\
\text { Perairan }(\%)\end{array}$ & 4 & $>75$ & 4 & $>50-75$ & 3 & $>25-50$ & 2 & $<25$ & 1 \\
\hline 3 & $\begin{array}{l}\text { Material } \\
\text { Dasar } \\
\text { Perairan }\end{array}$ & 4 & Pasir & 4 & $\begin{array}{l}\text { Karang } \\
\text { berpasir }\end{array}$ & 3 & $\begin{array}{l}\text { Pasir ber- } \\
\text { lumpur }\end{array}$ & 2 & lumpur & 1 \\
\hline 4 & Tipe Pantai & 7 & Berpasir & 4 & $\begin{array}{c}\text { Berpasir, } \\
\text { sedikit } \\
\text { karang }\end{array}$ & 3 & $\begin{array}{c}\text { Pasir \& } \\
\text { berkarang } \\
\text { sedikit } \\
\text { terjal }\end{array}$ & 2 & $\begin{array}{l}\text { Lumpur, } \\
\text { karang, } \\
\text { terjal, man- } \\
\text { grove }\end{array}$ & 1 \\
\hline 5 & $\begin{array}{l}\text { Penutupan } \\
\text { Lahan } \\
\text { Pantai }\end{array}$ & 3 & $\begin{array}{c}\text { Kelapa, } \\
\text { lahan } \\
\text { terbuka }\end{array}$ & 4 & $\begin{array}{c}\text { Semak, } \\
\text { belukar, } \\
\text { savana }\end{array}$ & 3 & $\begin{array}{c}\text { Belukar } \\
\text { tinggi }\end{array}$ & 2 & $\begin{array}{c}\text { Bakau, } \\
\text { pemukiman, } \\
\text { pelabuhan }\end{array}$ & 1 \\
\hline 6 & $\begin{array}{l}\text { Jarak Ke- } \\
\text { tersediaan } \\
\text { Air Tawar } \\
\text { (m) }\end{array}$ & 3 & $<500$ & 4 & $\begin{array}{l}500- \\
1000\end{array}$ & 3 & $\begin{array}{c}>1000- \\
2000\end{array}$ & 2 & $>2000$ & 1 \\
\hline
\end{tabular}

Sumber: Cahyadinata (2009) dengan modifikasi

Tabel 2. Matriks Kesesuaian Lahan untuk Ekowisata Bahari (Diving dan Snorkeling)

\begin{tabular}{|c|c|c|c|c|c|c|c|c|c|c|}
\hline \multirow{2}{*}{ No } & \multirow{2}{*}{ Parameter } & \multirow{2}{*}{ Bobot } & \multicolumn{8}{|c|}{ Kategori dan Skor } \\
\hline & & & Kategori & Skor & Kategori & Skor & Kategori & Skor & Kategori & Skor \\
\hline 1 & $\begin{array}{l}\text { Kecerahan } \\
\text { Perairan (\%) }\end{array}$ & 4 & $>75$ & 4 & $>50-75$ & 3 & $>25-50$ & 2 & $<25$ & 1 \\
\hline 2 & Jenis Karang & 4 & $>100$ & 4 & $>75-100$ & 3 & $>20-50$ & 2 & $<20$ & 1 \\
\hline 3 & $\begin{array}{l}\text { Jenis Ikan } \\
\text { Karang }\end{array}$ & 4 & $>70$ & 4 & $>50-70$ & 3 & $>20-50$ & 2 & $<20$ & 1 \\
\hline 4 & $\begin{array}{l}\text { Kedalaman } \\
\text { Perairan }(\mathrm{m})\end{array}$ & 3 & $>10-25$ & 4 & $>5-10$ & 3 & $>2-5$ & 2 & $<2$ & 1 \\
\hline
\end{tabular}

Sumber: Cahyadinata (2009) dengan modifikasi

Evaluasi terhadap parameter kesesuaian meliputi 4 (empat) kelas kriteria sebagai berikut: (1) Sangat Sesuai, jika nilai IKW 75-100\%; (2) Sesuai, jika nilai IKW 5074\%; (3) Sesuai Bersyarat, jika nilai IKW 25-49\%; dan (4) Tidak Sesuai, jika nilai IKW $<25 \%$.

\section{HASIL DAN PEMBAHASAN}

Evaluasi Kesesuaian Ekowisata Bahari untuk Rekreasi Pantai

Hasil evaluasi kesesuaian Pantai Teupin Layeu Iboih Kecamatan Sukakarya Kota Sabang sebagai lokasi ekowisata bahari untuk rekreasi pantai ditampilkan pada Tabel 3. 
Tabel 3. Kesesuaian Pantai Teupin Layeu Iboih Sebagai Lokasi Ekowisata Bahari untuk Rekreasi Pantai

\begin{tabular}{|c|c|c|c|c|c|c|}
\hline No & Parameter & Bobot & $\begin{array}{l}\text { Nilai } \\
\text { Maks }\end{array}$ & $\begin{array}{c}\text { Hasil } \\
\text { Observasi }\end{array}$ & $\begin{array}{l}\text { Skor Pe- } \\
\text { nilaian }\end{array}$ & $\begin{array}{l}\text { Nilai Parameter } \\
\text { (bobot x skor) }\end{array}$ \\
\hline 1 & $\begin{array}{l}\text { Kedalaman } \\
\text { Perairan }\end{array}$ & 4 & 16 & $0-5 \mathrm{~m}$ & 4 & 16 \\
\hline 2 & $\begin{array}{l}\text { Kecerahan } \\
\text { Perairan }\end{array}$ & 4 & 16 & $100 \%$ & 4 & 16 \\
\hline 3 & $\begin{array}{l}\text { Material Dasar } \\
\text { Perairan }\end{array}$ & 4 & 16 & $\begin{array}{l}\text { Berkarang, rubble, ber- } \\
\text { pasir }\end{array}$ & 3 & 12 \\
\hline 4 & Tipe Pantai & 7 & 28 & $\begin{array}{l}\text { Berpasir, berkarang, be- } \\
\text { batuan, sedikit terjal }\end{array}$ & 2 & 14 \\
\hline 5 & $\begin{array}{l}\text { Penutupan } \\
\text { Lahan Pantai }\end{array}$ & 3 & 12 & $\begin{array}{l}\text { Bakau, pemukiman, } \\
\text { pelabuhan, lahan terbuka }\end{array}$ & 1 & 3 \\
\hline \multirow[t]{2}{*}{6} & $\begin{array}{l}\text { Jarak Keter- } \\
\text { sediaan Air } \\
\text { Tawar }\end{array}$ & 3 & 12 & $<500 \mathrm{~m}$ & 4 & 12 \\
\hline & Jumlah & & 100 & & & 73 \\
\hline
\end{tabular}

$\mathrm{IKW}=\sum(\mathrm{Ni} / \mathrm{Nmaks}) \times 100 \%$

$=73 / 100 \times 100 \%$

$=73 \%$

Berdasarkan perhitungan Indeks kesesuaian ekowisata bahari untuk rekreasi pantai diperoleh nilai $73 \%$, yang menunjukkan bahwa Pantai Teupin Layeu Iboih sesuai sebagai kawasan ekowisata bahari untuk rekreasi pantai. Aktivitas wisata pada rekreasi pantai berupa aktivitas berjemur, bermain pasir, bermain air, renang, dan snorkeling bagi anak-anak dan pemula. Perairan yang dangkal merupakan salah satu syarat yang paling sesuai untuk rekreasi pantai, sehingga wisatawan dapat melakukan aktivitas wisata dengan aman. Kedalaman perairan yang digunakan untuk rekreasi pantai di Pantai Teupin Layeu Iboih adalah 0-5 meter, dengan jarak 25 meter dari bibir pantai.

Hasil pengukuran kecerahan diperoleh hasil 100\% untuk wilayah pantai yang diteliti, hal ini menunjukkan bahwa secara umum kondisi perairan masih dalam kondisi baik dan tidak ada pencemaran. Kecerahan perairan yang baik ini juga dipengaruhi oleh rendahnya turbulensi karena arus dan gelombang. Secara umum material dasar perairan di sepanjang Pantai Teupin Layeu Iboih adalah berkarang, berpasir dan terdapat patahan-patahan karang akibat jangkar kapal dan terinjak oleh wisatawan pada saat berwisata. Tipe pantai merupakan salah satu faktor fisik yang penting sehingga seringkali mewakili data-data fisik lainnya. Tipe Pantai Teupin Layeu Iboih adalah berpasir, berkarang, adanya bebatuan, dan 
pada bagian-bagian tertentu di sepanjang pantai berkondisi sedikit terjal, sehingga tidak semua wilayah pantai sesuai untuk kegiatan rekreasi pantai.

Seiring dengan rencana pengembangan dan perluasan lokasi wisata, penutupan lahan pantai merupakan salah satu faktor yang dapat berubah-ubah. Penutupan lahan Pantai Teupin Layeu Iboih pada saat ini tersusun atas vegetasi tumbuhan bakau di beberapa tempat, adanya pemukiman dan penginapan, adanya pelabuhan kapal sewaan dan kapal nelayan, dan sedikit lahan terbuka. Sumber tersedianya air bersih tidak sulit dicari, ada di beberapa titik di sepanjang pantai Teupin Layeu Iboih, dengan jarak berkisar dari 500 meter. Berdasarkan analisis keseluruhan parameter kesesuaian, maka hasil kesesuaian lahan di lokasi penelitian untuk rekreasi pantai adalah sesuai, hal ini dikarenakan tidak adanya faktor penghambat bagi parameter yang digunakan dalam menentukan kriteria sesuai tersebut.

\section{Evaluasi Kesesuaian Ekowisata Bahari untuk Diving dan Snorkeling}

Hasil evaluasi kesesuaian Pantai Teupin Layeu Iboih Kecamatan Sukakarya Kota Sabang sebagai lokasi ekowisata bahari untuk diving dan snorkeling ditampilkan pada Tabel 4.

$$
\begin{aligned}
\text { IKW } & =\sum(\mathrm{Ni} / \text { Nmaks }) \times 100 \% \\
& =52 / 60 \times 100 \% \\
& =86,7 \%
\end{aligned}
$$

Berdasarkan perhitungan Indeks kesesuaian ekowisata bahari untuk diving dan snorkeling diperoleh nilai 86,7\%, yang menunjukkan bahwa Pantai Teupin Layeu Iboih sangat sesuai sebagai kawasan ekowisata bahari untuk diving dan snorkeling. Snorkeling dan diving merupakan kegiatan yang berorientasi dalam menikmati keindahan berbagai terumbu karang dan biota perairan. Kegiatan tersebut juga sering dilakukan untuk mengetahui interaksi dan perilaku biota-biota dalam

Tabel 4. Kesesuaian Pantai Teupin Layeu Iboih sebagai Lokasi Ekowisata Bahari untuk Diving dan Snorkeling

\begin{tabular}{llccccc}
\hline No & \multicolumn{1}{c}{ Parameter } & Bobot & $\begin{array}{c}\text { Nilai } \\
\text { Maks }\end{array}$ & $\begin{array}{c}\text { Hasil } \\
\text { Observasi }\end{array}$ & $\begin{array}{c}\text { Skor } \\
\text { Penilaian }\end{array}$ & $\begin{array}{c}\text { Nilai Parameter } \\
\text { (bobot x skor) }\end{array}$ \\
\hline 1 & Kecerahan Perairan & 4 & 16 & $80 \%$ & 4 & 16 \\
2 & Jenis Karang & 4 & 16 & 21 spesies & 2 & 8 \\
3 & Jenis Ikan Karang & 4 & 16 & 71 spesies & 4 & 16 \\
4 & Kedalaman Perairan & 3 & 12 & $>10 \mathrm{~m}$ & 4 & 12 \\
\hline Jumlah & & 60 & & & 52 \\
\hline
\end{tabular}


suatu ekosistem terumbu karang. Namun pada beberapa wisatawan, pengalaman pada saat melakukan kegiatan diving lebih penting dari pada mengamati panorama kehidupan laut.

Berdasarkan hasil penelitian, pada kedalaman 10-18 meter kecerahan perairan adalah $100 \%$, namun pada kedalaman $>18$ 20 meter tingkat kecerahan perairan hanya $20 \%$, sehingga rerata kecerahan perairan adalah $80 \%$. Kecerahan $100 \%$ diperoleh mulai dari bibir pantai hingga jarak 128 $\mathrm{m}$ dari bibir pantai. Kedalaman perairan untuk sangat sesuai untuk wisata diving dan snorkeling, yaitu >10 meter, dan dibatasi hingga kedalam 18 meter, hal ini dipengaruhi oleh tingkat kecerahan perairan.

Formasi terumbu karang dapat dijumpai mulai kedalaman 2 hingga 20 meter. Jenis karang yang ditemukan terdiri 21 spesies dari 9 famili. Tiga famili yang paling banyak ditemukan pada lokasi penelitian adalah Faviidae, Poritidae dan Acroporidae. Nasir (2007) juga melaporkan dalam penelitiannya bahwa indeks keragaman karang di Pantai Teupin Layeun Sabang adalah tinggi dengan nilai 3.21, yang terdiri dari famili Acroporidae, Pocilloporidae, Siaderastreidae, Faviidae, Poritidae, dan Pectinidae.

Selain ditemukannya jenis karang yang masih hidup, di lokasi pengamatan juga dijumpai patahan-patahan karang (rubble) dan karang yang sudah mati. Kerusakan karang ini terjadi akibat terkena jangkar kapal karena adanya aktivitas pelayaran untuk para nelayan dan wisatawan yang memilih kegiatan wisata dengan mengelilingi Pulau Weh. Selain itu, kerusakan juga terjadi akibat terinjak oleh wisatawan pada saat melakukan aktivitas diving dan snorkeling.

Jenis karang yang ditemukan di lokasi pengamatan sangat bervariasi terdiri dari 71 spesies dari 22 famili. Tiga famili yang paling banyak dijumpai pada penelitian ini adalah Pomacentridae, Acanthuridae, dan Chaetodontidae. Hal serupa juga pernah dilaporkan oleh Nasir (2007), keragaman jenis ikan yang ditemukan di Teupin Layeun adalah 3.86, yang terdiri dari famili Acanthuridae, Chaetidontidae, Pomachanthidae, Pomacentridae, Labridae, Lutjanidae, Mulidae, Scaridae, Scorpaenidae, Zanclidae, Holocentridae, Serranidae, Nemipteridae, Centridae, dan Murainidae.

Untuk tercapainya pelaksanaan ekowisata bahari secara optimal, keragaman spesies karang dan ikan karang tentu menjadi salah satu faktor penting yang harus dipertimbangkan. Dalam penelitiannya, Rudi, et. al., (2012) mengemukakan bahwa jumlah total kekayaan spesies di Pulau Weh menurun sekitar 50\%. Hal ini juga dipengaruhi oleh rendahnya pengetahuan para nelayan terhadap pentingnya keragaman karang dan biota laut tersebut. Oleh sebab itu, perlu adanya upaya dalam 
Jurnal Penelitian Saintek, Vol. 20, Nomor 1, April 2015

perbaikan dan pengendalian pemanfaatan sumber daya laut, sehingga kegiatan wisata bahari yang menjadi salah satu andalan dari pengembangan pariwisata Sabang tetap terjaga. Stronza (2007) mengemukakan bahwa, saat ini para ahli konservasi telah mempromosikan ekowisata sebagai strategi untuk melindungi sumber daya alam namun tetap dapat memanfaatkan sumber daya tersebut untuk memenuhi kebutuhan manusia.

Hasil kesesuaian lahan di lokasi penelitian untuk aktivitas diving dan snorkeling adalah sangat sesuai, hal ini dikarenakan juga tidak adanya faktor penghambat bagi parameter yang digunakan dalam menetapkan kriteria sangat sesuai tersebut. Lokasi yang sangat sesuai untuk aktivitas diving dan snorkeling dimulai dari 57 meter dari bibir pantai sampai dengan jarak 126 meter dari bibir pantai.

Pengembangan ekowisata mengintegrasikan lingkungan dengan pembangunan berdasarkan pilar ekologi, ekonomi, sosial dan kelembagaan yang keberlanjutan (Sayyed, Mansoori, dan Jaybhaye, 2013). Oleh sebab itu, pelaksanaan ekowisata di Pantai Teupin Layeu Iboih harus mampu menciptakan serangkaian kegiatan untuk menarik wisatawan, menawarkan mereka sebuah kesempatan untuk berinteraksidengan alam dengan demikian memungkinkan mereka untuk melestarikan flora dan fauna yang ada di lokasi ekowisata tersebut. Selain itu, ekowisata juga memberi akses bagi penduduk setempat untuk mengelola lokasi ekowisata secara produktif dan berkelanjutan dalam menyediakan layanan wisata bagi wisatawan. Sumber daya ekowisata harus dimanfaatkan secara bijaksana agar sumber daya ini dapat terus dinikmati untuk generasi mendatang.

\section{KESIMPULAN}

Pantai Teupin Layeu Iboih memiliki kriteria sesuai sebagai kawasan ekowisata bahari untuk rekreasi pantai dengan nilai indeks kesesuaian ekowisata $73 \%$ dan sangat sesuai sebagai ekowisata bahari untuk diving dan snorkeling dengan nilai indeks kesesuaian ekowisata $86,7 \%$. Pengembangan ekowisata bahari di Pantai Teupin Layeu Iboih agar dapat optimal harus melibatkan masyarakat dan pemerintah setempat sehingga dapat memberikan keuntungan secara ekonomi dan kelestarian sumber daya alam dapat terjaga berkelanjutan.

\section{DAFTAR PUSTAKA}

Barkauskiene, K. and Vytautas, S. 2013. Ecotourism as an Integral Part of Sustainable Tourism Development. Jurnal Economics and Management,18(3), ISSN 2029-9338.

Cahyadinata, I. 2009. Kesesuaian Pengembangan Kawasan Pesisir Pulau Enggano untuk Pariwisata dan Perikanan Tangkap. Jurnal AGRISEP, 9(2): 168-182, Maret. 
Ketjulan, R. 2011. Daya Dukung Perairan Pulau Hari sebagai Obyek Ekowisata Bahari. Jurnal Aqua Hayati, 7 (3): 183188.

Nasir, M. 2007. Community-Driven Coral Conservation in Aceh, Indonesia. Final Report. A Report to Rufford Small Grant (for Nature Conservation). (Online). http://www.rufford.org, diakses 10 Juli 2014.

Ramadhani, E. dan Asep R. 2010. Correspondence Analysis on Public Service in Sabang Tourism Area. Jurnal Natural, 10(1), Maret.

Rudi, E., Iskandar, T., Fadli, N., Hidayati. 2012. Impact of Mass Coral Bleaching on Reef Fish Community and Fishermen Catches at Sabang, Aceh Province, Indonesia. AACL Bioflux, 5(5): 309320.

Sayyed, M.R.G. Mansoori, M.S. and Jaybhaye, R.G. 2013. SWOT Analysis of Tandooreh National Park (NE Iran) for Sustainable Ecotourism. Proceedings of the International Academy of Ecology and Environmental Sciences, 3(4): 296305.
Stronza, A.L. 2007. The Economic Promise of Ecotourism for Conservation. Journal of Ecotourism, 6(3): 210-21.

Stronza, A.L. 2010. Commons Management and Ecotourism: EthnographicEvidence from the Amazon. International Journal of the Commons, 4(1): 56-77, February.

Triyuniarthi, A.C. 2011. Konsep EkoWisata Bahari sebagai Pendekatan Pengembangan Produk Wisata Berkelanjutan di Pulau Lelei Kepulauan Guraici Kabupaten Halmahera SelatanMaluku Utara. Tesis, Tidak Dipublikasi. PPs UGM, Yogyakarta.

Tuwo, A. 2011. Pengelolaan Ekowisata Pesisir dan Laut-Pendekatan Ekologi, Sosial-Ekonomi, Kelembagaan, dan Sarana Wilayah. Surabaya: Brilian Internasional.

Zambrano, A.M.A. Eben, N.B., and William H.D. 2010. Social and Environmental Effects of Ecotourism in The Osa Peninsula of Costa Rica: the Lapa Rios case. Journal of Ecotourism, 9(1): 6283, March. 